\title{
STUDI KOMPARASI: MANAJEMEN PENGEMBANGAN BUDAYA RELIGIUS DI SMA NEGERI 5 YOGYAKARTA DAN MAN 1 YOGYAKARTA
}

\author{
Muhammad Iqbal Ma'ruf \\ Manajemen Pendidikan Islam, Pascasarjana, Universitas Muhammadiyah Yogyakarta \\ E-mail: Marufiqbal9@gmail.com
}

\begin{abstract}
ABSTRAK
Penelitian ini bertujuan untuk megetahui manajmen perencanaan, pelaksanaan, hasil dan tindak lanjut dan faktor-faktor pengembangan budaya religius. Penelitian ini menggunakan kualitatif dan data yang diperoleh melalui observasi, wawancara dan dokumen, kemudian uji keabsahan data menggunakan trianggulasi sumber, teknik, waktu, teknik analisis data menggunakan reduksi data, menyajikan data, dan menyimpulkan. Berdasarkan penelitian yang telah dilakukan menunjukkan hasil: Perbandingan manajemen perencanaan, pelaksanaan, hasil dan tindak lanjut, serta faktor yang mempengaruhi pengembangan budaya religius, dari segi perencanaan kedua sekolah memiliki perencanaan yang berbeda, kemudian segi pelaksanaanya memiliki kesamaan, hasil dan tindak lanjut memiliki kesamaan, serta faktor yang mempengaruhi memiliki perbedaan.
\end{abstract}

Kata Kunci: Manajemen Pendidikan, Budaya Religius, Pengembangan Budaya Religius.

\begin{abstract}
This research aims at identifying the management of planning, implementation, result and followups, and aspects of religious culture development. This research used a qualitative approach and the data were compiled through observation, interview, and documentation. Further, a validity test was done through triangulation of the source, technique, and time. The data analysis was done through the process of reduction, data presentation, and conclusion. Based on the research conducted, the results showed that: When compared, the management aspects of planning implementation, result and the follow-ups, and other influencing factors towards the religious development management at both schools are different. In terms of the planning, both schools' plans are different. In terms of implementation, and results and follow-ups, they share similarities. Whilst in terms of the influencing factors, they have differences.
\end{abstract}

Keywords: Education Management, Religious Culture, Religious Culture Development.

\section{PENDAHULUAN}

Upaya pembentukan karakter tidak hanya dilakukan disekolah melalui serangkaian pembelajaran di dalam dan di luar kelas, tetapi juga melalui pembiasaan sehari-hari, seperti penerapan nilai keagaaman, kejujuran, kedisiplinan, toleransi, tekun, tentram, amanah, serta lainnya. Pembiasaan tidak cuma terdiri dari menanamkan kognitif terkait benar dan salah, namun diharapkan bisa memiliki rasa untuk menilai mana yang baik serta tidak baik, dan bersedia melaksanakannya dari lingkungan di sekelilingnya, contohnya lingkungan keluarga dan yang lebih luas yakni lingkungan masyarakat. Nilai-nilai tersebut penting untuk dikembangkan dan terpatri dalam hati peserta didik sehingga menjadi lebih baik lagi dan menjadi ciri khas negera kita. Maka dari itu, sekolah mempunyai peran penting untuk mengembangkan kepribadian peserta didik, karena peranan sekolah yang menjadi sentral 
membiasakan budaya religius melalui pendekatan pengembangan budaya sekolah (school culture).

Nilai kepribadian sangat berarti buat dilaksanakan dalam pelaksanaan pengembangan kepribadian. Nilai tersebut akan menjadi hasil dari rangkaian penerapan pembelajaran serta budaya sekolah. Aspek pengetahuan, kesadaran, atau kemauan, tindakan untuk melaksanakaan nilai-nilai, baik untuk Allah SWT, diri sendiri, sesama, lingkungan maupun kebangsaan merupakan sebuah rangkaian pembiasaan menjadi insan kamil. Penguatan budaya religius salah satu dari banyak cara dalam membangaun karakter bangsa yang dimana penerapannya meliputi aktualisasi nilai pancasila, implementasi ajaran keagamaan, menjadi teladan.

Urgensi pengembangan budaya religius di sekolah agar seluruh warga sekolah, keimanannya sampai pada tahap keyakinan, praktik agama, pengalaman, pengetahuan agama, dan dimensi pengalaman keagamaan, dapat diwujudkan melalui berbagai kegiatan keagamaan sebagai wahana untuk menciptakan dan mengembangkan budaya religius. Diharapkan penanaman nilai-nilai agama di sekolah dapat diamalkan di lingkungan keluarga dan lingkungan masyarakat. Sekolah yang merupakan salah satu agen pembentukan karakter juga berperan aktif dalam menentukan keberhasilan moral bangsa. Setiap sekolah memiliki cara yang berbeda dalam menanamkan nilai-nilai religius pada peserta didik. Hal ini dipengaruhi oleh sistem, kondisi lingkungan sekitar dan lain sebagainya.

MAN 1 Yogyakarta sekolah dengan kurikulum keislmaan dan non-keislaman tentu memiliki perbedaan dalam cara pembentukan karakter religius peserta didik. SMA Negeri 5 Yogyakarta merupakan sekolah dengan heterogenitas latar belakang peserta didik, namun hal ini bukan menjadi penghambat bagi sekolah tersebut untuk mengembangkan budaya religius. Tujuan riset ini untuk mengambarkan, menjelaskan, serta mendeskripsikan manajemen perencanaan, pelaksanaan, hasil dan tindak lanjut serta faktor yang mempengaruhi kemudian perbandingan pengembangan budaya religius di sekolah tersebut.

\section{METODE PENELITIAN}

Penelitian kali ini menggunakan kualitatif lapangan dengan jenis studi kasus. Penelitian kualitatif diawali dengan hipotesis yang kemudian dijadikan sebagai landasan untuk menafsirkan dan memberikan pengaruh pada riset tentang permasalahan sosial. Peneliti memakai pendekatan antropologi dan sosiologi. Pendekatan antropologi merupakan studi yang menganalisis manusia serta budayanya. Pendekatan sosiologi 
merupakan studi yang mengkaji struktur sosial serta tahapan-tahapan terjadinya perubahan sosial. Sumber data ada dua yakni primer dan sekunder, data primer penelitian kali ini berasal dari data yang didapatkan melalui pengamatan, wawancara dan dokumen, sedangkan data sekunder merupakan kumpulan data-data pendukung untuk melengkapi. Teknik pengumpulan data yang digunakan yakni, observasi, wawancara dan dokumen, kemudian uji keabsahan data menggunakan trianggulasi sumber, teknik, dan waktu.

\section{HASIL DAN PEMBAHASAN}

1. Perencanaan Pengembangan Budaya Religius di SMA Negeri 5 Yogyakarta dan MAN 1 Yogyakarta

A. SMA Negeri 5 Yogyakarta

Sekolah yang memiliki brand sekolah berbasis afeksi yang memiliki berbagai rencana kegiatan pengembangan budaya religius. Rencana tersebut disusun tim pengembang sekolah meliputi, kepala sekolah selaku pemimpin, waka kurikulum, waka kesiswaan, waka afeksi, dan waka humas. Berdasarkan hasil wawancara, secara manajerial membentuk Waka afeksi yang orientasinya mewujudkan sesuatu program baik untuk guru berseta stakeholder sekolah maupun peserta didik.

Siagian berpendapat, perencanaan yakni proses tahapan-tahapan untuk dilakukan di masa yang akan datang dengan pemikiran dan penentuan yang matang sehingga mencapai tujuan yang diharapkan bersama. Sedangkan menurut Robbins and Coulter menyatakan dalam merencanakan sebaiknya harus menyusun target dan tujuan yang jelas, strategi yang jitu, sumber daya manusia dan alokasi yang tepat, waktu yang baik, sehingga dapat mencapai tujuan yang diinginkan.

Mengacu pernyataan ahli di atas peneliti mengaitkan dengan hasil yang diperoleh terkait perencanaan pengembangan budaya religius di SMA Negeri 5 Yogyakarta kenyataan yang terjadi prosesnya sudah sesuai dengan teori yang diungkapkan oleh para ahli tersebut.

B. MAN 1 Yogyakarta

Salah satu sekolah unggulan, MAN 1 Yogyakarta mempunyai ciri khusus yakni pendidikan Agama islam mendapatkan prioritas, dimana pedidikan agama islam mempunyai peren dalam pengembangan budaya religius perserta didik. Tim pengembang MAN 1 Yogyakarta menjadi penggerak dalam penyusunan program. Berdasarkan data yang didapatkan melalui wawancara, perencanaan program pengembangan budaya religius, waka kurikulum menjadi penggerak dalam proses 
pengembangan budaya religius serta prosesnya dilaksanakan dengan terstruktur dengan melalui tahapan evaluasi dan review kemudian baru dirumuskan dan di uji publik. Melihat proses yang terjadi peneliti mengambil point penting dalam merencakan sebuah progrram yakni komunikasi yang baik.

Siagian berpendapat, perencanaan yakni proses tahapan-tahapan untuk dilakukan di masa yang akan datang dengan pemikiran dan penentuan yang matang sehingga mencapai tujuan yang diharapkan bersama. Sedangkan menurut Robbins and Coulter menyatakan dalam merencanakan sebaiknya harus menyusun target dan tujuan yang jelas, strategi yang jitu, sumber daya manusia dan alokasi yang tepat, waktu yang baik, sehingga dapat mencapai tujuan yang diinginkan.

Mengacu pendapat ahli tersebut dengan kenyataan yang terjadi di lapangan secara teori yang disampaikan tahapan perencanaan pengembangan budaya religius di MAN 1 Yogyakarta sesuai dengan teori yang dikemukan oleh ahli.

2. Pelaksanaan Pengembangan Budaya Religius di SMA Negeri 5 Yogyakarta dan MAN 1 Yogyakarta

A. SMA Negeri 5 Yogyakarta

Proses perlaksanaan budaya religius di SMA Negeri 5 Yogyakarta sudah terlaksana dengan baik guru dapat memberikan teladan yang baik serta didukung dengan program yang dilaksanakan secara terstruktur, baik itu dalam kondisi offline sebelum pandemi, ataupun online saat pandemi. Sedangkan siswa yang melakukan program tersebut melaksanakan dengan senang dan bermanfaat untuk mereka. Menurut peneliti pelaksanaan budaya di SMA Negeri 5 Yogyakarta telah berjalan dengan efektif, koordinasi baik dari guru dan siswa juga berjalan dengan baik.

Langkah terwujudnya budaya religius pada sebuah lembaga pendidikan menurut Fathurrohman terdapat 2 metode yakni, dengan cara penurutan, peniruan, penganutan, dan penataan suatu skenario (tradisi, perintah) maka pola tersebut disebut pelakon sehingga budaya religius bisa terbentuk dengan cara seperti itu.

Kedua, pembentukan budaya terorganisir melalui proses pembelajaran. Cara ini berawal dari nurani pelaku, kepercayaan, keyakinan dasar yang dipegang teguh sebagai pendirian, dan diwujudkan melalui sikap dan tingkah laku. Kebenaran dapat diperoleh melalui pengalaman hasil mencoba dan membuktikan keyakinannya, proses ini merupakan bentuk olah rasa. 
Pendapat para ahli tersebut peneliti mengaitkan dengan pelaksanaan pengembangan budaya religius di SMA Negeri 5 Yogyakarta pola pembengangan budaya religius yang dinyatakan oleh ahli dan yang terjadi di lapangan sudah sesuai, guru menjadi teladan dan memberikan keyakinan terhadap peserta didik dan perserta didik juga melakukannya dengan baik.

B. MAN 1 Yogyakarta

Bedasarkan hasil wawancara proses pelaksanaan budaya religius di MAN 1 Yogykarta sudah berjalan dengan baik ditunjukkan dengen guru memberikan teladan untuk perserta didik dan didukung oleh tersusunnya program pengembangan budaya religius secara terstruktur serta sistematis, peserta didik juga melaksanakannya dengan baik dan di tengah kondisi pandemi ini juga pelaksanaan budaya religius sudah baik.

Langkah terwujudnya budaya religius pada sebuah lembaga pendidikan menurut Fathurrohman terdapat 2 metode yakni, dengan cara penurutan, peniruan, penganutan, dan penataan suatu skenario (tradisi, perintah) maka pola tersebut disebut pelakon sehingga budaya religius bisa terbentuk dengan cara seperti itu.

Kedua, pembentukan budaya terorganisir melalui proses pembelajaran. Cara ini berawal dari nurani pelaku, kepercayaan, keyakinan dasar yang dipegang teguh sebagai pendirian, dan diwujudkan melalui sikap dan tingkah laku. Kebenaran dapat diperoleh melalui pengalaman hasil mencoba dan membuktikan keyakinannya, proses ini merupakan bentuk olah rasa.

Menurut peneliti pendapat di atas dan kenyataannya yang terjadi di MAN 1 Yogyakarta terkait pelaksanaan pengembangan budaya religius sudah sesuai dengan yang di nyatakan oleh ahli, guru menjadi motor penggerak dan teladan budaya religius bagi peserta didik sedangkan perserta didik melaksanakan program tersebut dengan baik.

3. Hasil Penilaian dan Tindak Lanjut Pengembangan Budaya Religius di SMA Negeri 5 Yogyakarta dan MAN 1 Yogyakarta

A. SMA Negeri 5 Yogyakarta

Dari hasil wawanvara yang didapatkan, dari sebuah proses pelaksanaan program pengembangan budaya religius di SMA Negeri 5 Yogyakarta yang notabenya memiliki latar belakang agama peserta didik yang heterogen serta ditunjang dengan fasilitas sekolah untuk pelaksanaan pengembangan budaya religius maka peneliti mengambil kesimpulan hasil dan tindak lanjut dari 
penanaman budaya religius memang tidak bisa dilihat secara langsung namun perubahan sikap dan pengetahuan bisa dirasakan.

Mulyasa berpendapat bahwa implementasi merupakan suatu cara, penerapan gagasan, rancangan, aturan maupun pembaruan dalam tindakan nyata sehingga berdampak pada perkembangan pemahaman, keahlian, maupun sikap.

Terkait hasil dan tindak lanjut pengembangan budaya religius di SMA Negeri 5 Yogyakarta peneliti menyimpulkan proses yang terjadi penerapan ide dan konsep yang diterapkan di SMA 5 Yogyakarta sudah apik serta terjadinya perubahan perilaku dan peningkatan pemahaman pengentahun perserta didik. Artinya teori yang diungkapkan oleh ahli mampu diterapkan dengan baik oleh SMA Negeri 5 Yogykarta.

B. MAN 1 Yogyakarta

Dari hasil wawamcara terkait hasil dan tindak lanjut pengembangan budaya religius di MAN 1 Yogykartaka memiliki siswa berbagai macam latar belakang, dengan adanya program budaya yang terprogram tentunya ada perubahan sikap dan perilaku perserta didik, sedangkan untuk tindaknya lanjutnya itu sendirinya program yang telah dilaksanakan harus konsisten.

Mulyasa berpendapat bahwa implementasi merupakan suatu cara, penerapan gagasan, rancangan, aturan maupun pembaruan dalam tindakan nyata sehingga berdampak pada perkembangan pemahaman, keahlian, maupun sikap.

Menurut penyataan ahli, peneliti melihat kesamaan teori dengan kenyataan yang terjadi pada MAN 1 Yogyakarta, penerapan ide serta konsep dan kebijakan MAN 1 Yogyakarta terkait pengembangan budaya religus menunjukkan hasil baik dan meningkatkan pengetahuan serta perilaku peserta didik.

4. Faktor Yang Mempengaruhi Pengembangan Budaya Religius di SMA Negeri 5 Yogyakarta dan MAN 1 Yogyakarta

A. SMA Negeri 5 Yogyakarta

Dari hasil wawancara, maka dalam hal ini faktor yang mempengaruhi pengembangan budaya religius di SMA Negeri 5 Yogyakarta yang memiliki latar belakang agama siswa yang heterogen dalam pelaksanaan pembiasaan budaya religius berjalan dengan baik, dan tentunya ada beberapa yang menjadi catatan dalam prosesnya yakni pengembangan budaya religius merupakan penanaman nilai-nilai sehingga ingin melihat outputnya secara instan, kemudian konsisten 
menjadi sebuah catatan penting dalam pengembangan budaya religius dan erat kaitannya kekompakkan guru dalam memberikan teladan kepada siswa.

Perlu dipahami bahwa pengembangan budaya religius tidak lepas dari kinerja guru. Guru sebagai pendidik menurut Al-Ghazali adalah orang besar yang aktivitasnya lebih baik dari pada ibadah setahun. Pendidik dalam Islam adalah spiritual father atau bapak rohani bagi murid. Gurulah yang memberi santapan jiwa dengan ilmu, pendidikan akhlak dan membenarkannya.

Menurut peneliti, pendapat yang dikemukakan oleh ahli dan kenyataannya yang terjadi di SMA Negeri 5 Yogyakarta guru menjadi pioner dalam pengembangan budaya religius di sekolah guru memberikan teladan dalam bentuk sikap dan perilaku serta memberikan pemahaman secara konsep.

B. MAN 1 Yogyakarta

Menurut penyataan wawancara di atas, maka faktor pengembangan budaya religius di MAN 1 Yogyakarta dapat disimpulkan. Pertama, branding yang begitu kuat menjadikan sebagai madrasah yang memiliki keunggulan keagamaan menjadi faktor pendukung dalam pengembangan budaya religius di sekolah, terlihat dari mata pelajaran keagamaan yang lebih banyak serta program keagamaan yang mendukung, kemudian faktor alumni serta kepercayaan orang tua, kemudian faktor penghambat dalam pengembangan budaya religius yakni semangat dan kemauan yang belum konsisten serta tidak sinkronnya antara guru, orang tua dan peserta didik.

Perlu dipahami bahwa pengembangan budaya religius tidak lepas dari kinerja guru. Guru sebagai pendidik menurut Al-Ghazali adalah orang besar yang aktivitasnya lebih baik dari pada ibadah setahun. Pendidik dalam Islam adalah spiritual father atau bapak rohani bagi murid. Gurulah yang memberi santapan jiwa dengan ilmu, pendidikan akhlak dan membenarkannya.

Peneliti menyimpulkan terkait pendapat ahli dan kenyataan yang terjadi di MAN 1 Yogyakarta, guru yang menjadi penggerak dalam mengembangan budaya religius di MAN 1 Yogyakarta dan dengan sekolah yang mempunyai branding keagamaan membuat pengembangan budaya religius berjalan dengan baik. guru memberikan teladan serta konsep religus dengan baik.

5. Perbandingan Manajemen Perencanaan, Pelaksanaan, Hasil Penilaian dan Tindak Lanjut, serta Faktor yang Mempengaruhi Pengembangan Budaya Religius di SMA Negeri 5 Yogyakarta dan MAN 1 Yogyakarta 
Pada penjelasan di atas tersebut, maka dapat dijelaskan terkait perbandingan manajemen perencanaan, pelaksanaan, hasil dan tindak lanjut, serta faktor yang mempengaruhi pengembangan budaya religius dikedua sekolah tersebut. sebagaimana perbandingannya sebagai berikut.

Perencanaan pengembangan budaya religius di SMA Negeri 5 Yogyakarta dan MAN 1 Yogyakarta peneliti menyimpulkan kedua sekolah terdapat cara yang berbeda dalam merencanakan program. SMA Negeri 5 Yogykarta menambahkan waka afeksi pada struktur organisasinya. Kemudian yang merencanakan program pengembangan budaya religius baik untuk siswa ataupun guru di koordinator oleh tim afeksi. Sedangkan MAN 1 Yogykarta tim kurikulum menjadi penggerak dalam perencanaan pengembangan budaya religius dan dalam merencanakan program religius dengan mengadakan evaluasi yang rutin hingga mengundang ahli dan diuji publik.

Pelaksanaan pengembangan budaya religius di SMA Negeri 5 Yogyakarta dengan cara guru berusaha semaksimal mungkin memberikan teladan yang baik serta didukung dengan program yang dilaksanakan secara terstruktur, baik itu dalam kondisi offline sebelum pandemi, ataupun online saat pandemi. Secara keseluruhan pengembangan budaya religius di SMA Negeri 5 Yogyakarta dilaksanakan dengan baik. Sedangkan proses pelaksanaan budaya religius di MAN 1 Yogykarta telah terlaksana dengan baik ditunjukkan melalui guru memberikan teladan untuk perserta didik dan didukung tersusunnya program pengembangan budaya religius secara terstruktur serta sistematis. Di tengah kondisi pandemi ini juga pelaksanaan budaya religius sudah baik.

Hasil dan tindak lanjut pengembangan budaya religius di SMA Negeri 5 Yogyakarta yang memiliki latar belakang agama peseerta didik yang heterogen penanaman budaya religius memang tidak bisa dilihat secara langsung namun perubahan sikap dan pengetahuan bisa dirasakan serta tindak lanjut pengembangan budaya religius harus berjalan dengan konsisten. Sedangkan di MAN 1 Yogykartaka yang basisnya sekolah keagamaan dan latar belakang agama siswa yang homogen adanya program budaya yang terprogram tentunya ada perubahan sikap dan perilaku perserta didik, sedangkan untuk tindak lanjutnya itu sendirinya program yang telah dilaksanakan harus konsisten.

Faktor yang mepengaruhi pengembangan budaya religius di SMA Negeri 5 Yogyakarta yang memiliki latar belakang agama siswa yang heterogen pelaksanaan pembiasaan budaya religius berjalan dengan baik, dan tentunya ada beberapa yang menjadi faktor yang mempengaruhi dalam prosesnya pengembangan budaya religius 
merupakan penanaman nilai-nilai sehingga ingin melihat outputnya secara instan, kemudian konsisten menjadi sebuah catatan penting dalam pengembangan budaya religius dan erat kaitannya kekompakkan guru dalam memberikan teladan kepada siswa. Sedangkan di MAN 1 Yogyakarta, maka faktor pengembangan budaya religius di MAN 1 Yogyakarta. Pertama, branding yang begitu kuat menjadikan sebagai madrasah yang memiliki keunggulan keagamaan menjadi faktor pendukung dalam pengembangan budaya religius di sekolah, terlihat dari mata pelajaran keagamaan yang lebih banyak serta program keagamaan yang mendukung, kemudian faktor alumni serta kepercayaan orang tua, kemudian faktor penghambat dalam pengembangan budaya religius yakni semangat dan kemauan yang belum konsisten serta tidak sinkronnya antara guru, orang tua dan peserta didik.

Dari pembahasan tersebut maka dapat dilihat dalam bentuk tabel perbandingan manajemen pengembangan budaya religius di SMA Negeri 5 Yogyakarta dan MAN 1 Yogyakarta, adalaha sebagai berikut:

\begin{tabular}{|c|c|c|c|}
\hline No & Perbandingan & SMA Negeri 5 Yogyakarta & MAN 1 Yogyakarta \\
\hline 1 & Perencanaan & $\begin{array}{l}\text { Membentuk tim waka } \\
\text { efeksi }\end{array}$ & $\begin{array}{l}\text { Tim waka Kurikulum menjadi } \\
\text { penggerak dalam program } \\
\text { pengembangan budaya religius }\end{array}$ \\
\hline 2 & Pelaksanaan & $\begin{array}{l}\text { Guru sebagai teladan, dan } \\
\text { pelaksaanya terlaksana } \\
\text { dengan terstruktur dan } \\
\text { sistematis }\end{array}$ & $\begin{array}{l}\text { Guru sebagai teladan, dan } \\
\text { pelaksaannya terlaksana } \\
\text { tersturuktur dan sistematis }\end{array}$ \\
\hline 3 & $\begin{array}{l}\text { Hasil dan } \\
\text { Tindak } \\
\text { Lanjut }\end{array}$ & $\begin{array}{l}\text { Memiliki latar belakang } \\
\text { agama peserta didik yang } \\
\text { heterogen hasil dari } \\
\text { pengembangan budaya } \\
\text { religius adanya perubahan } \\
\text { sikap dan pengetahuan. } \\
\text { Dan tindak lanjutnya harus } \\
\text { dilaksanakan secara } \\
\text { konsisten }\end{array}$ & $\begin{array}{l}\text { Mempunyai latar belakang agama } \\
\text { peserta didik yang homogen. Hasil } \\
\text { dari pengembangan budaya religius } \\
\text { yakni ada perubahan sikap dan } \\
\text { pengetahuan. Serta tindak lanjutnya } \\
\text { program harus dilaksanakan secara } \\
\text { konsisten }\end{array}$ \\
\hline 4 & Faktor-faktor & $\begin{array}{l}\text { Memiliki latar belakang } \\
\text { agama peserta didik yang } \\
\text { heteorogen, kemudian } \\
\text { ingin melihat hasilnya } \\
\text { secara instan, dan } \\
\text { konsestensi kekompakkan } \\
\text { guru dalam menjadi } \\
\text { teladan }\end{array}$ & $\begin{array}{l}\text { Faktor branding sekolah, faktor mata } \\
\text { pelajaran keagamaan yang lebih } \\
\text { banyak, faktor alumni. Kemudian } \\
\text { faktor penghambatnya semangat dan } \\
\text { kemauan yang belum konsisten dan } \\
\text { belum singkrongnya antara guru, } \\
\text { orang tua, dan siswa }\end{array}$ \\
\hline
\end{tabular}


Di tinjau dari sudut pandang manajemen pendidikan islam, menururt Muhaimin dkk mengartikan manajemen pendidikan Islam adalah proses perencanaan, pengorganisasian, pengarahan dan pengendalian sumber daya pendidikan Islam untuk mencapai tujuan pendidikan Islam secara efektif dan efesien.

Sementara itu Mujamil Qomar menjelaskan sebagai suatu proses pengelolaan lembaga pendidikan Islam secara islami dengan cara menyiasati sumbersumber belajar dan hal-hal lain yang terkait untuk mencapai tujuan pendidikan Islam secara efektif dan efesien.

Ramayulis yakni proses pemanfaatan semua sumber daya yang dimiliki (ummat Islam, lembaga pendidikan atau lainnya) baik perangkat keras maupun lunak. Pemanfaatan tersebut dilakukan melalui kerjasama dengan orang lain secara efektif, efisien, dan produktif untuk mencapai kebahagiaan dan kesejahteraan baik di dunia maupun di akhirat.

Dari beberapa pendapat ahli tersebut, kemudian dikaitkan dengan pengembagan budaya religius di SMA Negeri 5 Yogyakarta dan MAN 1 Yogyakarta proses manajemen pengembangan budaya religius yakni ada beberapa tahapan di mulai dari perencanaan, pelaksanaan, hasil dan tindak lanjut serta faktor-faktor yang mempengarhui sudah tepat dalam mengaplikasikan teori tersebut, serta sumber daya manusia diberdayakan dengan maksimal kemudian untuk sarana dan prasarana untuk mencapai pengembangan budaya religius yang maksimal dikelola secara islami dan produktif.

\section{SIMPULAN}

Perencanaan pengembangan budaya religius di SMA Negeri 5 Yogyakarta dan MAN 1 Yogyakarta peneliti menyimpulkan kedua sekolah terdapat cara yang berbeda dalam merencanakan program. SMA Negeri 5 Yogykarta menambahkan waka afeksi pada struktur organisasinya. Kemudian yang merencanakan program pengembangan budaya religius baik untuk siswa ataupun guru di koordinator oleh tim afeksi. Sedangkan MAN 1 Yogykarta salah satu sekolah unggulan berbasis agama dalam merencanakan program religius dengan mengadakan evaluasi yang rutin hingga mengundang ahli dan diuji publik.

Pelaksanaan pengembangan budaya religius di SMA Negeri 5 Yogyakarta dan MAN 1 Yogyakarta dapat disimpulkan telah terlaksana dengan baik baik dalam kondisi di tengah pandemi covid-19 serta dalam pelaksanaannya tersusun dan sistemasis. 
Hasil dan tindak lanjut pengembangan budaya religius di SMA Negeri 5 Yogyakarta dengan latar belakang agama yang heterogen penanaman budaya religius memang tidak bisa dilihat secara langsung namun perubahan sikap dan pengetahuan bisa dirasakan serta tindaknya pengembangan budaya religius harus berjalan dengan konsisten. Sedangkan di MAN 1 Yogykartaka yang basicnya sekolah keagamaan dan latar belakang agama siswa yang homogen adanya program budaya yang terprogram tentunya ada perubahan sikap dan perilaku perserta didik, sedangkan untuk tindaknya lanjutnya itu sendirinya program yang telah dilaksanakan harus konsisten.

Faktor yang mepengaruhi pengembangan budaya religius di SMA Negeri 5 Yogyakarta yang memiliki latar belakang agama siswa yang heterogen pelaksanaan pembiasaan budaya religius berjalan dengan baik, dan tentunya ada beberapa yang menjadi faktor yang mempengaruhi dalam prosesnya pengembangan budaya religius merupakan penanaman nilai-nilai sehingga ingin melihat outputnya secara instan, kemudian konsisten menjadi sebuah catatan penting dalam pengembangan budaya religius dan erat kaitannya kekompakkan guru dalam memberikan teladan kepada siswa. Sedangkan di MAN 1 Yogyakarta, maka faktor pengembangan budaya religius di MAN 1 Yogyakarta. Pertama, branding yang begitu kuat menjadikan sebagai madrasah yang memiliki keunggulan keagamaan menjadi faktor pendukung dalam pengembangan budaya religius di sekolah, terlihat dari mata pelajaran keagamaan yang lebih banyak serta program keagamaan yang mendukung, kemudian faktor alumni serta kepercayaan orang tua, kemudian faktor.

Perbandingan manajemen perencanaan, pelaksanaan, hasil dan tindak lanjut, serta faktor yang mempengaruhi pengembangan budaya religius, dari segi perencanaan kedua sekolah memiliki perencanaan yang berbeda, kemudian segi pelaksanaanya memiliki kesamaan, hasil dan tindak lanjut memiliki kesamaan, serta faktor yang mempengaruhi memiliki perbedaan.

\section{SARAN}

Mengacu pada hasil penelitian dan kesimpulan, ada beberapa saran yang ingin peneliti sampaikan terkait pengembangan budaya religius di SMA Negeri 5 Yogyakarta dan MAN 1 Yogyakarta, sebagai berikut:

1. Melakukan berbagai inovasi terkait pengembangan budaya religius supaya sikap religius tertanam pada perserta didik.

2. Perlu peningkatan terkait pelaksanaan pengembangan budaya religius di tengah pandemi covid-19. 
3. Kedepannya supaya dilaksanakan penelitian lebih lanjut yang dapat mengungkap lebih dalam terkait pengembangan budaya religius di sekolah.

\section{DAFTAR PUSTAKA}

Assegaf, A. R. 2011. Filsafat Pendidikan Islam: Paradigma Baru Pendidikan Hadhari Berbasis Integratif-Interkonektif. Jakarta: Rajawali Pers.

Fathurrohman, M. 2015. Budaya Religius dalam Peningkatan Mutu Pendidikan; Tinjauan Teoritik dan Praktik Kontekstualisasi Pendidikan Agama di Sekolah. Yogyakarta: Kalimedia.

Kurnia, H., \& Wahono, J. (2021). PENGARUH KECERDASAN EMOSIONAL TERHADAP PRESTASI BELAJAR PENDIDIKAN PANCASILA DAN KEWARGANEGARAAN SISWA SMA NEGERI 5 YOGYAKARTA. Academy of Education Journal, 12(1), 82-97. https://doi.org/10.47200/aoej.v12i1.431

Muhaimin dan Abdul, M. 1993. Pemikiran Pendidikan Islam: Kajian Filosofi dan Kerangka Dasar Operasionalnya. Bandung: Trigenda Karya.

Muhaimin, dkk. 2010. Manajemen Pendidikan, Aplikasinya dalam Penyusunan Rencana Pengembangan Sekolah/Madrasah. Jakarta: Prenada Media Group.

Mulyasa. 2009. Implementasi Kurikulum Tingkatsatua Pendidikan. Jakarta: Bumi Aksara.

Nuryati, N., \& Ari Bowo, A. (2015). Pengembangan Model Pembelajaran PPKn Quantum Teaching Berbasis Lingkungan melalui Cooperative Learning di SMA Negeri kota Yogyakarta. Academy of Education Journal, 6(2). https://doi.org/10.47200/aoej.v6i2.128

Qomar, M. 2007. Manajemen Pendidikan Islam Strategi baru Pengelolaan Lembaga Pendidikan Islam. Jakarta: Penerbit Erlangga.

Ramayulis. 2011. Ilmu Pendidikan Islam. Jakarta: Kalam Mulia.

Robbins, S. P and Mary. C. 2006. Manajemen. Jakarta: Indeks Kelompok Gramedia.

Siagian, S. P. 2012. Teori Pengembangan Organisasi. Jakarta: Bumi Aksara.

Supriyati, P. (2019). Meningkatkan Kemampuan Berbicara Monolog Teks Recount dengan Metode Demonstrasi Media Picture Series. Academy of Education Journal, 10(02), 122-130. https://doi.org/10.47200/aoej.v10i02.275 